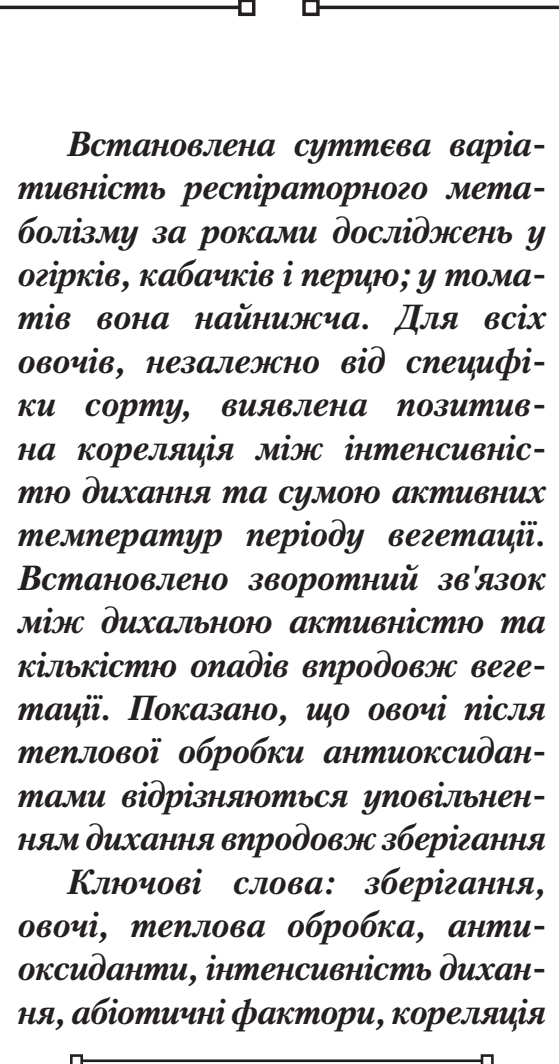

Установлена существенная вариативность респираторного метаболизма по годам исследований у огуриов, кабачков и перца, у томатов она самая низкая. Для всех овощей, независимо от специфики сорта, выявлена положительная корреляция между интенсивностью дыхания и суммой активных температур периода вегетации. Установлена обратная связь между дыхательной активностью и количеством осадков во время вегетации. Показано, ито овощи после тепловой обработки антиоксидантами отличаются замедлением дыхания при хранении

Ключевые слова: хранение, овощи, тепловая обработка, антиоксиданты, интенсивность дыхания, абиотические факторы, корреляция

\section{EFFECT OF ABIOTIC FACTORS ON THE RESPIRATION INTENSITY OF FRUIT VEGETABLES DURING STORAGE}

O. Priss

Doctor of Technical Sciences, Associate Professor* E-mail: olesyapriss@gmail.com

V. Ev las h

Doctor of Technical Sciences, Professor Department of Chemistry, Microbiology and Nutritional Hygiene Kharkiv State University of Food Technology and Trade Klochkivska str., 333, Kharkiv, Ukraine, 61051 E-mail: evlashvv@gmail.com

V. Z h u k ova PhD, Senior Lecturer* E-mail: zhuzhuvf@gmail.com

S. Ki u r che v $\mathrm{PhD}$, Professor Department of structural materials technology** E-mail: dec.tgatu@ukr.net

V.Verkholant seva $\mathrm{PhD}$, Senior Lecturer Department of Processing and Food Production Equipment named after professor F. Yalpachik**

E-mail: wer.valentina@gmail.com

I. K a I u gina

PhD, Associate Professor*** E-mail: ik101273@gmail.com

S. Ko les n i che n k o $\mathrm{PhD}$, Associate Professor*** E-mail: svetlanalk@ukr.net

A. Salavelis

PhD, Associate Professor***

E-mail: onapta@ukr.net

O. Zolovska

$\mathrm{PhD}$, Associate Professor*** E-mail: zolovska.lena@gmail.com

H. B a n d u r e n k o

$\mathrm{PhD}$, Associate Professor

Department of food technology

Kyiv Cooperative Institute of Business and Law Lomonosova str., 18, Kyiv, Ukraine, 03022

E-mail: gbandurenko@ukr.net

*Department of Technology of Processing and

Storage of Agricultural Products**

**Tavria State Agrotechnological University

B. Khmelnytskoho ave., 18, Melitopol, Ukraine, 72310 $\star * *$ Department of restaurant and health promoting catering

Odessa National Academy of Food Technologies Kanatna str., 112, Odessa, Ukraine, 65039

\section{Introduction}

Results of the research carried out by a group of experts on climate change from the World Meteorological Organi- zation of the United Nations unambiguously indicate that the development of global warming cannot be questioned [1]. A change in the climatic activity, which is characteristic of the present time, is taking place extremely rapidly, which 
is not typical for natural cycles [2]. A critical restructuring of climate-forming factors negatively affects the quality and storability of agricultural crops since it makes full adaptation of the biological species to the ultra-fast climate changes impossible [3].

Stressful conditions of changing climate make vegetable growing more and more difficult every year, while fruit quality becomes a hard-to-predict phenomenon. Nonspecific changes in weather and climatic conditions require chronobiological analysis. It is difficult to forecast the storability and preservation of plastic substances without thorough research into metabolic behavior of fruits in response to abiotic factors. Any innovative developments and proposals to producers will be ineffective.

Plant organisms demonstrate physiological variability as a consequence of changes in weather and climate conditions [4]. An increase in the temperature of the environment directly affects photosynthesis, which alters the level of sugars, organic acids and phenolic substances in fruits [5]. Agricultural crops quickly react to external signals and adapt to them by adjusting the mechanisms of their development. Plant gene pools in a retrospect of their development formed resistant mechanisms of adaptation to climatic fluctuations [6]. The gene pool of vegetable crops should have a sufficient constant of strength against the effects of changes in abiotic factors. That is why it is important to know critical threshold values of abiotic factors at which there is a risk of loss of fruit vegetables storability.

\section{Literature review and problem statement}

Stress factors, including adverse temperature and humidity conditions, high solar activity in the period of growing, play a crucial role in the formation of storability of fruits, adding risk to the post-harvest quality. The oxidative stress to which they are exposed during vegetation predetermines intracellular accumulation of active oxygen forms (AOF) and, as a consequence, natural imbalance in the internal antioxidant fruit-protection systems.

Without the implementation of additional measures of protection for adaptation, this can extremely adversely affect duration of storage. Innovative technologies that are now being actively implemented in production imply the post-harvest produce treatment with antioxidant compositions [7]. The application of antioxidants effectively prevents development of a cold stress in fruits during storage [8]. Scientists designed a number of preparations with antioxidant effect, the treatment with which contributes to the enhanced cold tolerance of vegetables [9] and fruits [10]. When a negative or a damaging impact of abiotic factors on the quality of fruit vegetables during storage exceeds the degree of adaptation capability, the use of exogenous antioxidant treatments makes it possible to reduce the level of vulnerability, as well as to improve stability of fruits in the dynamics of storage [11].

In response to damaging factors, specific processes are initiated in fruits, which synthesize the production of protective substances, such as proteins of heat shock, proteins-antifreezes, phytochelatins, polyamines [12]. Thus, the cells that were exposed to the action of one stress factor (heat) acquire resistance to the effect of other damaging factors. In other words, there is a cross-adaptation. The post-harvest thermal treatment of fruits with antioxidants has proven its high efficiency [13]. By providing the fruits with an under-threshold stress state, such a treatment enhances endogenous mechanisms of stability during storage.

After harvesting, the fruits continue to undergo vital physiological processes, the most important of which is the respiratory metabolism [14]. The intensity of vegetable respiration during storage is an indicator for quantitative estimation of the response of fruits to the changes in climatic conditions. Research in this direction will determine the degree of vulnerability of fruit objects depending on the abiotic extrema. In addition, still unclear is the impact of thermal treatment of fruits with antioxidants on the variability of respiration dynamics. The study of this aspect is compulsory in order to ensure efficient storage of fruit and vegetable produce.

\section{The aim and objectives of the study}

The aim of present study was to establish the influence of abiotic factors on the intensity of respiration of the fruits of tomato, pepper, cucumber, and zucchini during storage. This will make it possible to predict the storability of each type of vegetables and modify it by using thermal treatment with antioxidants.

To achieve the aim, the following tasks have been set:

- to clarify the adaptive potential of fruits by analyzing the influence of abiotic factors on respiratory metabolism during storage;

- to explore the mechanism of influence of the post-harvest thermal treatment with antioxidants on the respiratory activity of fruit vegetables during storage;

- to analyze the degree of influence of such factors as varietal and species specificity and meteorological conditions of cultivation on the respiration intensity (RI) the of fruits.

\section{Research methods and materials}

\section{1. Research materials}

The research was performed over 2005-2012 at the Tavriya State Agrotechnological University (Melitopol, Ukraine). The fruit vegetables were grown under conditions of drip irrigation in the south of Zaporizhia oblast, Ukraine. The area of cultivation is characterized by high heat supply (the annual total of temperatures above $10^{\circ} \mathrm{C}$ is $3,400 \ldots 3,600$ ) and the lowest humidity in Ukraine (annual hydrothermal factor (HTF) is 0.5...0.7 units) [15]. Irrigation rate was maintained in the range of $30-90 \mathrm{~m}^{3} / \mathrm{ha}$, in some cases $-110-130 \mathrm{~m}^{3} / \mathrm{ha}$. The agricultural technological techniques for the cultivation of fruit vegetables are standard for the zone of dry steppe.

The materials and methods of research are described in detail in paper [16].

\section{Results of research of the influence of abiotic factors on the respiration intensity of fruit vegetables during storage}

The research results demonstrate varietal specificity of the respiratory activity of cucumbers of both hybrids. Before storing, the released $\mathrm{CO}_{2}$ level for the fruit of Athena hybrid is almost 2 times higher than that for Masha: 31.73 vs $16.75 \mathrm{mg} \mathrm{CO} / \mathrm{kg} \cdot \mathrm{h}$ (Table 1 ). 
Table 1

Intensity of cucumber respiration before storing, $\mathrm{mgCO}_{2} / \mathrm{kg} \times \mathrm{h}, \bar{x} \pm s \bar{x}, n=3$

\begin{tabular}{|c|c|c|}
\hline Year of research & Athena & Masha \\
\hline 2005 & $43.87 \pm 0.87$ & $17.06 \pm 0.60$ \\
\hline 2006 & $30.97 \pm 0.29$ & $16.89 \pm 0.19$ \\
\hline 2007 & $22.44 \pm 0.28$ & $16.44 \pm 0.27$ \\
\hline 2008 & $20.10 \pm 0.96$ & $15.02 \pm 0.04$ \\
\hline 2009 & $37.39 \pm 0.27$ & $16.91 \pm 0.05$ \\
\hline 2010 & $32.95 \pm 0.67$ & $17.67 \pm 0.11$ \\
\hline 2011 & $25.07 \pm 0.28$ & $14.00 \pm 0.19$ \\
\hline 2012 & $41.01 \pm 1.35$ & $20.02 \pm 0.16$ \\
\hline average & 31.73 & 16.75 \\
\hline$V, \%$ & 27.51 & 10.67 \\
\hline $\mathrm{HIP}_{0.95}$ & 2.35 & 0.75 \\
\hline $\mathrm{Sx} \%$ & 2.44 & 1.48 \\
\hline
\end{tabular}

Variability for the cucumber Athena is significant, $V=27.51 \%$, while it is average for the cucumber Masha, $V=10.67 \%$. Similar patterns were revealed in the amount of $\mathrm{CO}_{2}$ released by the cucumbers and the abiotic factors during cultivation. Maximally close dependences are observed for total of active temperatures (TAT) above $10^{\circ} \mathrm{C}$ during the formation of cucumbers of both hybrids (Fig. 1).

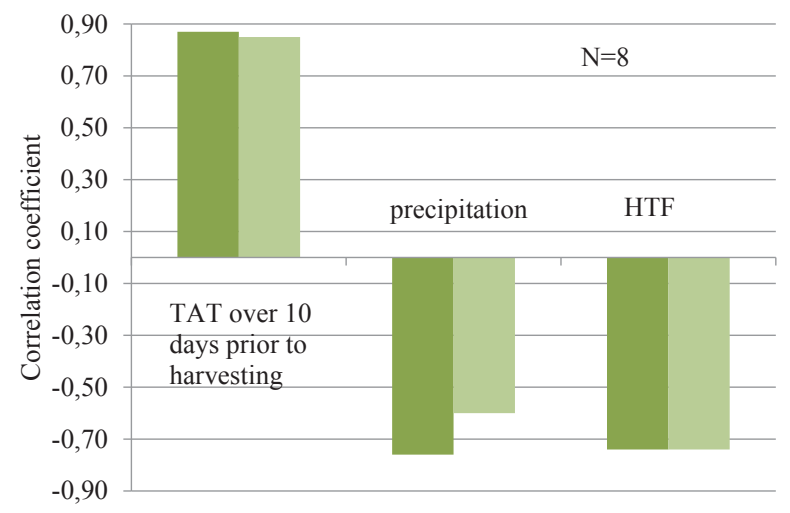

Fig. 1. Dependence of the intensity of cucumber respiration on weather factors: $\square-$ Athena; $\square-$ Masha

A two-factor variance analysis showed that the key role in RI of cucumbers belongs to the varietal specificity (factor A). Significant influence is exerted by the year of research (factor B), as well as the interaction between factors (Fig. 2).

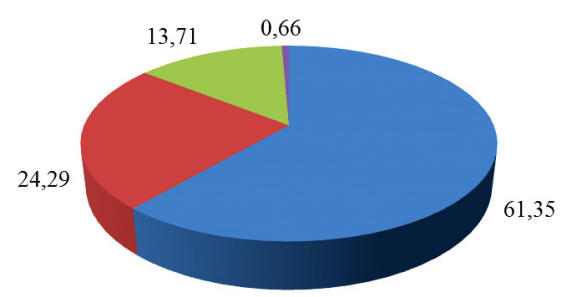

Fig. 2. Share of influence of factors on the intensity of cucumber respiration: - cucumber hybrid; - - year of research; $\square-$ interaction between factors; $\square-$ the rest

RI dynamics during storage of cucumbers is similar for both hybrids (Fig. 3). In day one of the fruits' storing, RI slows for all variants, due to the natural reaction of cucumber tissue to a decrease in temperature [17].
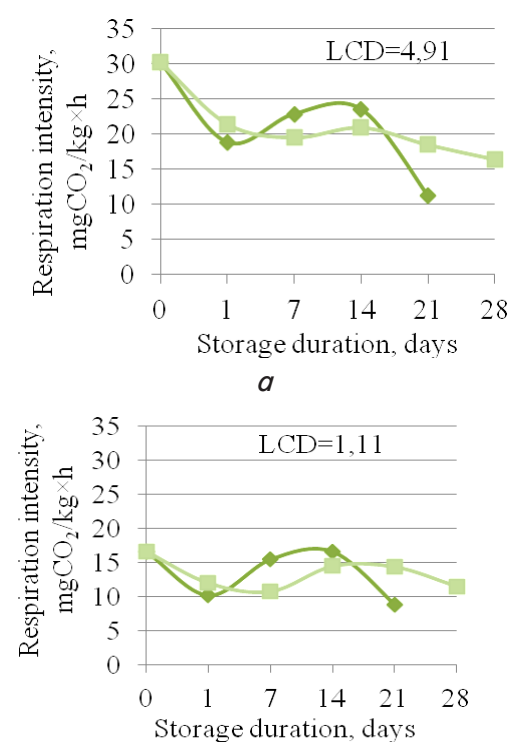

$b$

Fig. 3. Dynamics of respiration intensity of cucumber:

$$
a \text { - Athena; } b \text { - Masha; }
$$

$\checkmark--$ control; --- thermal treatment $\mathrm{Chl}+\mathrm{I}+\mathrm{L}$

Zucchini are characterized by high respiratory activity [7]. Studies have shown that RI during placement to a cooling chamber is affected, similar to cucumbers, by varietal specificity and cultivation conditions (Table 2).

Table 2

Respiration intensity of zucchini before storing, $\mathrm{mg} \mathrm{CO} / 2 / \mathrm{kg} \times \mathrm{h}, \bar{x} \pm s \bar{x}, n=3$

\begin{tabular}{|c|c|c|}
\hline Year of research & Kavili & Tamino \\
\hline 2005 & $56.54 \pm 0.85$ & $70.55 \pm 0.75$ \\
\hline 2006 & $29.03 \pm 1.00$ & $51.05 \pm 0.97$ \\
\hline 2007 & $32.90 \pm 0.28$ & $61.06 \pm 0.43$ \\
\hline 2008 & $58.84 \pm 0.81$ & $69.16 \pm 0.56$ \\
\hline 2009 & $36.51 \pm 0.18$ & $55.47 \pm 0.67$ \\
\hline 2010 & $34.15 \pm 0.20$ & $57.06 \pm 0.76$ \\
\hline 2011 & $16.87 \pm 0.23$ & $40.80 \pm 0.58$ \\
\hline 2012 & $44.56 \pm 0.18$ & $61.90 \pm 0.62$ \\
\hline average & 38.68 & 58.38 \\
\hline$V, \%$ & 36.40 & 16.59 \\
\hline $\mathrm{HIP}_{0.95}$ & 1.72 & 1.78 \\
\hline $\mathrm{Sx}, \%$ & 1.46 & 1.00 \\
\hline
\end{tabular}

The dependence of zucchini RI on abiotic factors was proved by high correlation (Fig. 4).

The obtained dependences are similar to those of cucumbers by force and orientation. Zucchini RI is largely affected by the year of research (factor B), with a strong influence by the hybrid (factor A) (Fig. 5).

The natural model of respiration of non-climacteric fruits during storage is a slow decline regardless of temperature for the fruits resistant to cooling, and when cooling above the temperature of cold threshold for those sensitive to cooling [18]. 


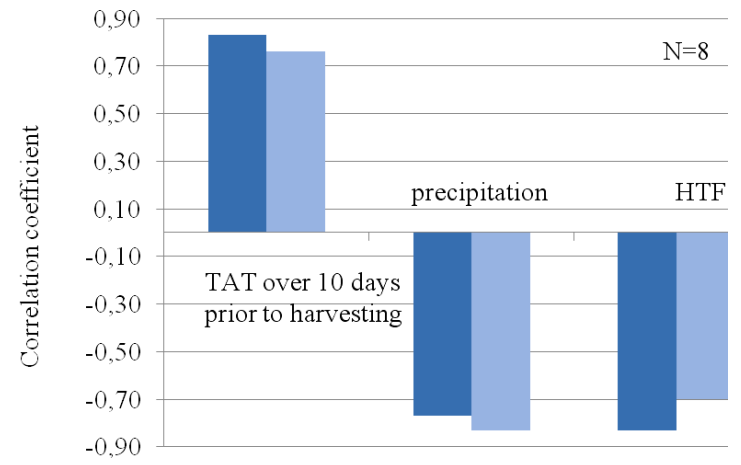

Fig. 4. Dependence of respiration intensity of zucchini on weather factors: - Kavili; $\square-$ Tamino

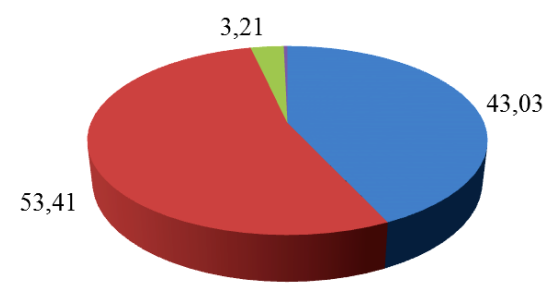

Fig. 5. Share of influence of factors on the respiration intensity of zucchini: - zucchini hybrid; - - year of research; $\square-$ interaction between factors; $\square-$ the rest

Different features of RI dynamics were identified during storage of zucchini (Fig. 6).

The fruits of pepper are characterized by the average level of RI [19]. According to the results, fruits' RI immediately after harvesting was about $43 \mathrm{mg} \mathrm{CO} / \mathrm{kg} \times \mathrm{h}$, but the variability over years of research was significant: $V=37 \%$ (Table 3).

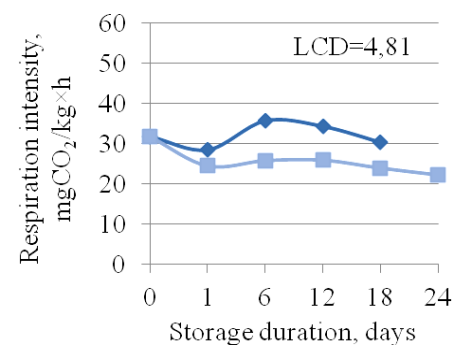

a

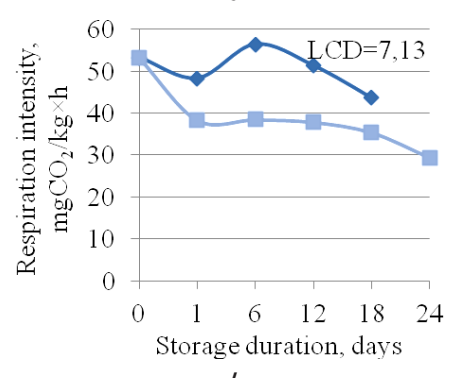

$b$

Fig. 6. Dynamics of the respiration intensity of zucchini: $a-$ Kavili; $b$ - Tamino;

$\checkmark-$ control; --- thermal treatment $\mathrm{Chl}+\mathrm{I}+\mathrm{L}$

Close correlation connection between RI and weather conditions was established at the total of active temperatures of the formation and maturation of fruits: $r=0.95$ for Hercules, 0.92 for Nikita (Fig. 7).
Table 3

Respiration intensity of pepper before storing, $\mathrm{mg} \mathrm{CO}_{2} / \mathrm{kg} \times \mathrm{h} x \pm s x, n=3$

\begin{tabular}{|c|c|c|}
\hline Year of research & Hercules & Nikita \\
\hline 2005 & $42.23 \pm 0.81$ & $49.51 \pm 0.74$ \\
\hline 2006 & $35.84 \pm 0.89$ & $29.37 \pm 1.12$ \\
\hline 2007 & $70.92 \pm 1.64$ & $77.45 \pm 1.96$ \\
\hline 2008 & $53.45 \pm 1.26$ & $63.25 \pm 0.62$ \\
\hline 2009 & $22.17 \pm 0.50$ & $30.02 \pm 1.20$ \\
\hline 2010 & $43.32 \pm 0.44$ & $47.22 \pm 2.39$ \\
\hline 2011 & $39.32 \pm 1.08$ & $31.73 \pm 0.83$ \\
\hline 2012 & $24.64 \pm 0.26$ & $41.16 \pm 0.46$ \\
\hline average & 41.49 & 46.21 \\
\hline$V, \%$ & 37.64 & 37.11 \\
\hline $\mathrm{HIP}_{0.95}$ & 3.03 & 3.90 \\
\hline $\mathrm{Sx}, \%$ & 2.40 & 2.78 \\
\hline
\end{tabular}

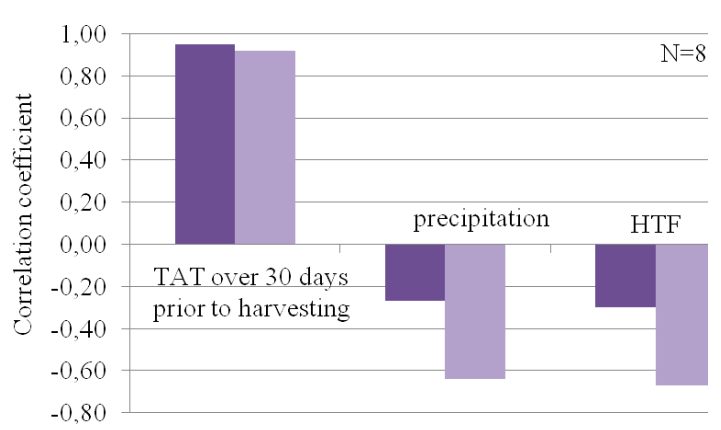

Fig. 7. Dependence of the respiration intensity of pepper on weather factors: $\square-$ Hercules; $\square-$ Nikita

A two-factor analysis indicates a significant dependence between cultivation conditions and the level of RI. The share of influence of given factor is larger than $90 \%$ (Fig. 8).

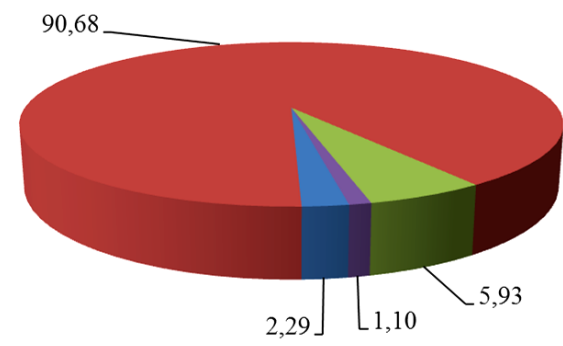

Fig. 8. Share of influence of factors on the respiration intensity of pepper: $\square-$ pepper hybrid; $\square$ - year of research; - - interaction between factors; $\square-$ the rest

As is known, pepper can belong either to a climacteric or a non-climacteric group of fruits depending on the type and variety [20]. Different scientists observed the emergence of climacteric rises in the respiratory amplitude when studying fruits at incomplete stage of ripeness and while growing $[21,22]$. According to data, a characteristic feature of respiratory curve for the treated fruits is the absence of the respiratory rise over the entire storage duration (Fig. 9).

Tomato RI is significantly affected by the variety, degree of ripeness, and storage temperature [23]. It was established that the tomato RI after harvesting is around $10 \mathrm{mg} \mathrm{CO} / \mathrm{kg} \times \mathrm{h}$. The coefficient of variation is insignificant for the variety 
Novachok $(V=8.32)$ and average for the variety Rio Grande, $V=13.3 \%$ (Table 4).

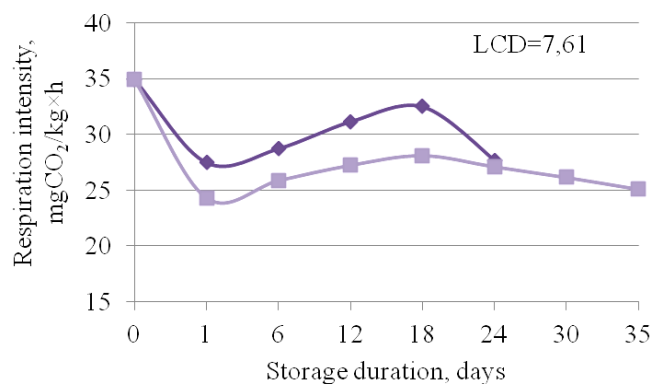

Fig. 9. Dynamics of respiration intensity of pepper, the hybrid Hercules:

$\checkmark-$ control; -- thermal treatment $\mathrm{Chl}+\mathrm{I}+\mathrm{L}$

Table 4

Respiration intensity of tomato before storing, $\mathrm{mg} \mathrm{CO}_{2} / \mathrm{kg} \times \mathrm{h}, \bar{x} \pm s \bar{x}, n=3$

\begin{tabular}{|c|c|c|}
\hline Year of research & Rio Grande & Novachok \\
\hline 2005 & $12.33 \pm 0.38$ & $10.35 \pm 0.27$ \\
\hline 2006 & $12.60 \pm 0.57$ & $10.49 \pm 0.11$ \\
\hline 2007 & $10.90 \pm 0.03$ & $10.54 \pm 0.24$ \\
\hline 2008 & $10.79 \pm 0.34$ & $10.55 \pm 0.58$ \\
\hline 2009 & $10.48 \pm 0.55$ & $9.77 \pm 0.49$ \\
\hline 2010 & $9.65 \pm 0.32$ & $9.03 \pm 0.67$ \\
\hline 2011 & $8.11 \pm 0.30$ & $8.51 \pm 0.27$ \\
\hline 2012 & $10.73 \pm 0.38$ & $9.09 \pm 0.25$ \\
\hline average & 10.70 & 9.79 \\
\hline $\mathrm{V}, \%$ & 13.29 & 8.32 \\
\hline $\mathrm{HIP}$ & 1.22 & 1.29 \\
\hline Sx, $\%$ & 3.74 & 4.35 \\
\hline
\end{tabular}

Closer correlation connections between RI and weather factors are observed for TAT during formation and maturation of fruits: $r=0.90$ for the variety Novachok, and 0.58 for the variety Rio Grande (Fig. 10).

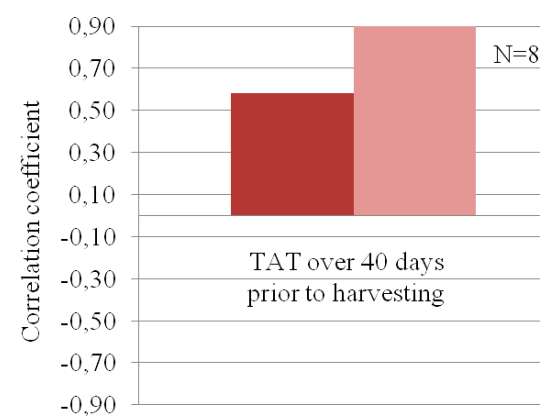

Fig. 10. Dependence of the respiration intensity of tomato on weather factors: $\quad$ - Novachok; $\square$ - Rio Grande

A share of the influence of a vegetation conditions factor on the level of respiration is larger than $58 \%$ (Fig. 11).

When comparing the examined kinds of vegetables, one can see that only tomato is unambiguously climacteric (Fig. 12).

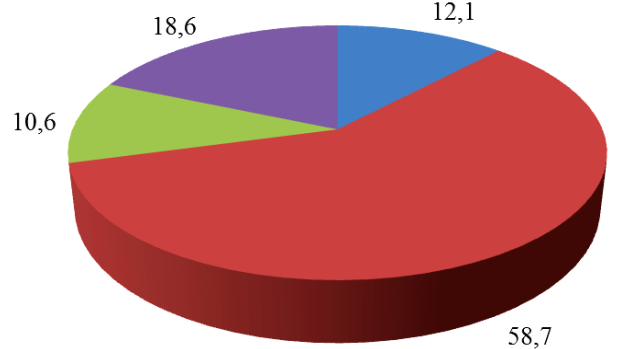

Fig. 11. Share of the influence of factors on the respiration intensity of tomato: - - tomato variety; $\mathbf{-}$ - vegetation conditions; - - interaction between factors; $1-$ the rest

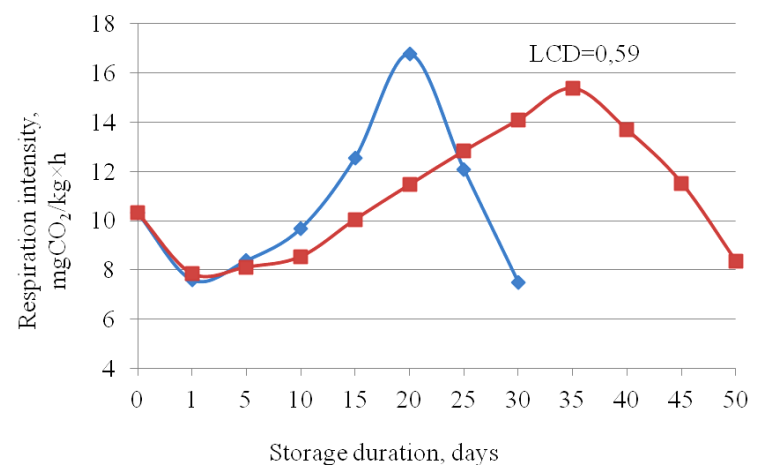

Fig. 12. Dynamics of the respiration intensity of tomato, the variety Rio Grande:

$\checkmark-$ control; --- thermal treatment $\mathrm{Chl}+\mathrm{I}+\mathrm{L}$

In the course of research, we registered the climacterix during storage of tomato. The peak of respiratory activity in the control samples occurs on day 20.

\section{Discussion of results of the study of influence of abiotic factors on the respiration intensity of fruit vegetables during storage}

\section{1. Cucumber}

Cucumber is a non-climacteric fruit, but there are cases of explosive ethylene-formation during storage, which is followed by a start of the accelerated maturation and by the loss of chlorophyll [24], which indicates a respiratory rise similar to the climacteric one. Some researchers detect a rise in the respiration intensity on day three of storing cucumbers, which is explained by the unbalanced phosphoric feed when growing [25]. The level of carbon dioxide production by cucumber during storage is affected by many factors: variety, storing modes, a degree of cold damage, etc.

We established a direct dependence of RI on TAT (Fig. 1) of the formation period of the cucumber. As is known, a rise in temperature increases the respiratory activity of plants [26]. Inverse correlation with precipitation during vegetation period is quite normal because respiratory and transpiratory processes are interrelated.

An increase in the level of $\mathrm{CO}_{2}$ occurs in the group of control fruits over 2 weeks of storing (Fig. 3). Afterwards, we established a rapid decrease in respiratory activity.

The specificity of RI dynamics in the treated fruits has certain peculiarities. The minimum level of $\mathrm{CO}_{2}$ in the variants with thermal treatment with antioxidants $\mathrm{Chl}+\mathrm{I}+\mathrm{L}$ is observed not in the first day of storing but a week later. 
Some scientists believe that the respiration rate slowdown is caused not only by the fact of cooling, but also by the thermal treatment of fruits and by the antioxidant effect [7, 12].

Next, we registered a slight increase in the level of $\mathrm{CO}_{2}$ up to day 14 and day 21, followed by a gradual decrease in RI at the end of storing. Such a character of respiratory metabolism indicates the balance of metabolic processes in the examined variants.

\section{2. Zucchini}

Control groups of fruits of two hybrids throughout all years of research slightly slowed down RI in one day after cooling (Fig. 6). In a week, we observed restoration and growth of RI, which indicates their considerable sensitivity to a temperature drop, even in the absence of visual damage. As noted by other experts in the field of zucchini storing, a sharp rise in respiration, by $1.5 \ldots 2$ times, is observed after cold damage [18, 27, 28]. Results confirm the absence of significant damage after cooling, which could provoke the emergence of "explosive" growth of $\mathrm{CO}_{2}$. The amplitude of respiratory activity of the hybrid Kavili is 1.5 times lower in comparison with the variety Tamino. As data reveal, RI of the cold-sensitive hybrid Kavili increases by 1.25 times; that of the tolerant variety Tamino - by 1.16 times only.

The experimental variants are characterized by the more intensive slow-down in RI as a result of thermal treatment with antioxidants and storing at lower temperatures. Restoration of the level of respiratory activity is not observed; after a long lag phase (18 days), there is a slow decline of RI. Such a pattern of respiratory dynamics indicates the absence of metabolic disruptions, as well as normal work of plant tissues.

After 12 days of storing, when control groups exhibit loss of quality, the respiratory activity of the experimental variants is lower by 1.3 times.

\section{3. Pepper}

After cooling the fruits of pepper, RI is gradually inhibited (Fig. 9). A more intensive slow-down of respiration activity in the treated variants is associated with the synergistic effect of decreased temperature and thermal treatment with antioxidants. The capability of antioxidants to slow down RI of pepper was proven by American scientists [28]; the effectiveness of thermal treatment - by researchers from China [29].

A gradual growth of RI occurs after 6 days of storing. In 18 days, control variants significantly reduce a level of the released carbon dioxide, which is associated with aging and loss of quality of pepper fruits.

The treated variants of two hybrids demonstrate a slight fluctuation in the amount of $\mathrm{CO}_{2}$ during storage, which makes it possible to better preserve plastic substances, compared to control, as well as confirms inhibiting effect of the chosen treatment.

Over the entire storage period, respiratory activity of the experimental variants of pepper is $15 \%$ lower than that in control groups.

\section{4. Tomato}

Respiratory curve is similar in both varieties of tomato (Fig. 12). Immediately after harvesting RI is inhibited as a reaction to cooling. After 5 days of storing, control groups show active growth of RI. Respiratory maximum occurs on day 20 of storing, then we observed fading respiratory activity, dominated by overripening processes, which is indicated by the deterioration of fruit quality.

Tomato after thermal treatment is characterized by typical climacterix [30]. Treating it with antioxidants contributes not only to the prolongation of emergence of respiratory maximum by 15 days, but also to the reduction in its level by $9 \%$ compared to control. Inhibition of RI in the experimental variants is caused by biochemical and physical reactions to the thermal treatment with antioxidants that reduce the rate of $\mathrm{O}_{2}$ absorption by mitochondria and slow down the motion of electrons in the cytochromic direction of respiration, which results in the reduction of the level of released $\mathrm{CO}_{2}$ [30]. In addition, a coating that appears on the surface of tomato after treatment inhibits gas-exchange processes. Limited access of $\mathrm{O}_{2}$ slows the evolution of ethylene in fruits since the ethylene-forming enzyme is fully oxygen-dependent [31], which decreases the respiratory maximum.

Research results have revealed patterns of change in the respiratory activity of fruits depending on weather-climatic conditions of cultivation. Data analysis allowed us to understand the mechanism for improving storability of fruits after treating them thermally with antioxidants. Owing to such a technological technique, it is possible to significantly prolong duration of storage of fruit vegetables, which could be employed in the industry.

A possible weakness of present work is the study into influence of abiotic factors only on the dynamics of respiration intensity. Further studies are needed to establish the dependence of dynamics of respiratory substrates and enzymes on weather factors. This is actually the direction of subsequent research. However, to determine metabolic responses of tissues of fruit vegetables on the abiotic stress factors, it is necessary to explore the dynamics of all physiological-biochemical processes, which is rather difficult given the multicomponent nature of the system.

\section{Conclusions}

1. We identified the influence of abiotic factors on the respiratory metabolism of fruits during storage. Close patterns were revealed between the amount of $\mathrm{CO}_{2}$ released by cucumber during storage and abiotic factors during cultivation. We established a positive correlation between RI and TAT of the fruit formation period for all examined vegetables regardless of varietal specificity. An inverse connection of varying strength depending on the kind of culture was found between RI and the amount of precipitation and HTF in the process of growing.

2. We examined the mechanism of influence of the post-harvest thermal treatment with antioxidants on the respiratory activity of fruit vegetables during storage. The intensity of respiration of the treated fruits is much lower than that in control groups. For tomato, the thermal treatment with antioxidants contributes not only to delaying the emergence of respiratory maximum for 15 days, but also to reducing its level by $9 \%$ compared to control.

3. We analyzed the degree of influence of such factors as varietal and species specificity and meteorological conditions of cultivation on the intensity of respiration of fruits. Key role in RI cucumber belongs to varietal specificity $(61.35 \%)$. Before storing, the level of the released $\mathrm{CO}_{2}$ for 
the fruits of hybrid Athena is almost 2 times higher than that for the variety Masha. Significant influence is also exerted by weather conditions of the year of research (24.29\%).

Zucchini RI is to a large extent affected by the meteorological conditions of cultivation (53.41\%), with a strong influence from the hybrid (43.03\%).

For the fruits of pepper, we established a close correlation connection between RI and weather conditions and the total of active temperatures during formation and ripening of fruits: $r=0.95$ for the variety Hercules and 0.92 for the variety Nikita. A two-factor analysis indicates a significant dependence of RI on the conditions of pepper cultivation - a share of influence of this factor is over $90 \%$.
Close correlation connections between tomato RI and weather factors are observed with TAT during the formation and ripening of fruits: $r=0.90$ for the variety Novachok and 0.58 for the variety Rio Grande. A share of influence of a vegetation conditions factor on the level of respiration is more than $58 \%$.

We established a considerable variability of respiratory metabolism over the years of research for cucumber of the hybrid Athena (27.51\%), for zucchini of the variety Kavili (36.40\%), for pepper of both hybrids (37\%), which indicates a rapid reaction of tissue on the fluctuations in abiotic factors. For tomato, variability of respiratory activity over the years of research is the lowest $(13.29 \%)$.

\section{References}

1. The Global Climate in 2011-2015 [Text]. - World Meteorological Organization. - 2016. - No. 1179. - 32 p.

2. Malkin, I. G. Warnings of the World Meteorological Organization of the Paris Conference on Climat [Text] / I. G. Malkin // Philosophy and Humanities in the Information Society. - 2017. - Issue 1 (15). - P. $46-87$.

3. Proskuryakov, M. A. Chronobiological analysis of plants under climate change [Text] / M. A. Proskuryakov. - Almaty: LEM, 2012. 228 p. - Available at: http://elar.usfeu.ru/handle/123456789/5262

4. Peter, M. A. Abiotic Stress in Harvested Fruits and Vegetables [Text] / M. A. Peter, D. Mark // Abiotic Stress in Plants Mechanisms and Adaptations. - Intech, 2011. doi: 10.5772/22524

5. Moretti, C. L. Climate changes and potential impacts on postharvest quality of fruit and vegetable crops: A review [Text] / C. L. Moretti, L. M. Mattos, A. G. Calbo, S. A. Sargent // Food Research International. - 2010. - Vol. 43, Issue 7. - P. $1824-1832$. doi: 10.1016/j.foodres.2009.10.013

6. Ibragimov, K. H. Problems of the development of horticulture in Russia in a changing climate [Text] / K. H. Ibragimov // Bulletin of the Uman National University of Horticulture. - 2014. - Issue 1. - P. 105-107. - Available at: http://nbuv.gov.ua/UJRN/ vumnuc_2014_1_25

7. Mahajan, P. V. Postharvest treatments of fresh produce [Text] / P. V. Mahajan, O. J. Caleb, Z. Singh, C. B. Watkins, M. Geyer // Philosophical Transactions of the Royal Society A: Mathematical, Physical and Engineering Sciences. - 2014. - Vol. 372, Issue 2017. - P. 20130309-20130309. doi: 10.1098/rsta.2013.0309

8. Toivonen, P. M. A. Benefits of combined treatment approaches to maintaining fruit and vegetable quality [Text] / P. M. A. Toivonen // Fresh Produce. - 2009. - Vol. 3. - P. 58-64.

9. Wang, C. Y. Alleviation of chilling injury in tropical and subtropical fruits [Text] / C. Y. Wang // Proceedings of the III International symposium on tropical and subtropical fruits. - Fortaleza, Ceara, Brazil, 2010. - P. 267-274. doi: 10.17660/actahortic.2010.864.35

10. Serdyuk, M. Development of fruit diseases of microbial origin during storage at treatment with antioxidant compositions [Text] / M. Serdyuk, D. Stepanenko, O. Priss, T. Kopylova, N. Gaprindashvili, A. Kulik et. al. // Eastern-European Journal of Enterprise Technologies. - 2017. - Vol. 3, Issue 11 (87). - P. 45-51. doi: 10.15587/1729-4061.2017.103858

11. Priss, O. P. Reduction of losses during storage of low temperature sensitive vegetables [Text] / O. P. Priss, V. V. Kalitka // Progressive technique and technologies of food production of restaurant economy and trade. - 2014. - Issue 1. - P. 209-221. Available at: http://nbuv.gov.ua/UJRN/Pt_2014_1_28

12. Lurie, S. Fundamental aspects of postharvest heat treatments [Text] / S. Lurie, R. Pedreschi // Horticulture Research. - 2014. Vol. 1. - P. 14030. doi: 10.1038/hortres.2014.30

13. Serdyuk, M. E. Use of antioxidant drugs to prevent biotic and abiotic stress during the storage of fruits and berries [Text] / M. E. Serdyuk // Chemistry. Agronomy. Service. - 2010. - Issue 7. - P. 52-53.

14. Saltveit, M. E. Respiratory metabolism [Text] / M. E. Saltveit; K. C. Gross, C. Y. Wang, M. Saltveit (Eds.) // Agricultural handbook number 66: The commercial storage of fruits, vegetables and florist and nursery stocks. US Dept. Agr., Washington, 2007.

15. Lyashenko, G. V. Agroclimatic zoning of Ukraine [Text] / G. V. Lyashenko // Ukrainian Hydrometeorological Journal. - 2008. Issue 3. - P. 98-108.

16. Priss, O. Investigation of the respiration rate during storage of fruit vegetables under the influence of abiotic factors [Text] / O. Priss, V. Evlash, V. Zhukova, S. Kiurchev, V. Verkholantseva, I. Kalugina et. al. // EUREKA: Life Sciences. - 2017. - Issue 6. P. 10-15. doi: 10.21303/2504-5695.2017.00494

17. Eaks, I. L. Respiration of Cucumber Fruits Associated with Physiological Injury at Chilling Temperatures [Text] / I. L. Eaks, L. L. Morris // Plant Physiology. - 1956. - Vol. 31, Issue 4. - P. 308-314. doi: 10.1104/pp.31.4.308

18. Valenzuela, J. Oxidative Stress Associated with Chilling Injury in Immature Fruit: Postharvest Technological and Biotechnological Solutions [Text] / J. Valenzuela, S. Manzano, F. Palma, F. Carvajal, D. Garrido, M. Jamilena // International Journal of Molecular Sciences. - 2017. - Vol. 18, Issue 7. - P. 1467. doi: 10.3390/ijms18071467 
19. González-Aguilar, G. A. Pepper [Text] / G. A. González-Aguilar; K. C. Gross, C. Y. Wang, M. Saltveit (Eds.) // Agricultural handbook number 66: The commercial storage of fruits, vegetables, and florist and nursery stocks. - US Dept. Agr., Washington, 2007.

20. Rattanawan, J. Managing chilli (Capsicum spp.) quality attributes: the importance of pre-harvest and postharvest factors [Text] / J. Rattanawan. - New Zealand, 2012. - 238 p.

21. Gross, K. C. Biochemical changes associated with the ripening of hot pepper fruit [Text] / K. C. Gross, A. E. Watada, M. S. Kang, S. D. Kim, K. S. Kim, S. W. Lee // Physiologia Plantarum. - 1986. - Vol. 66, Issue 1. - P. 31-36. doi: 10.1111/j.1399-3054.1986. tb01227.x

22. Krajayklang, M. Colour at harvest and post-harvest behaviour influence paprika and chilli spice quality [Text] / M. Krajayklang, A. Klieber, P. R. Dry // Postharvest Biology and Technology. - 2000. - Vol. 20, Issue 3. - P. 269-278. doi: 10.1016/s09255214(00)00141-1

23. Sargent, S. A. Tomato [Text] / S. A. Sargent, C. L. Moretti // Agricultural handbook number 66: The commercial storage of fruits, vegetables, and florist and nursery stocks. - US Dept. Agr., Washington, 2007.

24. Hurr, B. M. Developmentally dependent responses of detached cucumber (Cucumis sativus L.) fruit to exogenous ethylene [Text] / B. M. Hurr, D. J. Huber, C. E. Vallejos, S. T. Talcott // Postharvest Biology and Technology. - 2009. - Vol. 52, Issue 2. - P. 207-215. doi: 10.1016/j.postharvbio.2008.12.006

25. Knowles, L. Phosphorus status affects postharvest respiration, membrane permeability and lipid chemistry of European seedless cucumber fruit (Cucumis sativus L.) [Text] / L. Knowles, M. R. Trimble, N. R. Knowles // Postharvest Biology and Technology.2001. - Vol. 21, Issue 2. - P. 179-188. doi: 10.1016/s0925-5214(00)00144-7

26. Atkin, O. K. Evans Review No. 2: The hot and the cold: unravelling the variable response of plant respiration to temperature [Text] / O. K. Atkin, D. Bruhn, V. M. Hurry, M. G. Tjoelker // Functional Plant Biology. - 2005. - Vol. 32, Issue 2. - P. 87. doi: 10.1071/ fp03176

27. Balandrán-Quintana, R. R. Irreversibility of chilling injury in zucchini squash (Cucurbita pepo L.) could be a programmed event long before the visible symptoms are evident [Text] / R. R. Balandr n-Quintana, A. M. Mendoza-Wilson, A. A. Gardea-Béjar, I. Vargas-Arispuro, M. Angel Martínez-Téllez // Biochemical and Biophysical Research Communications. - 2003. - Vol. 307, Issue 3. - P. 553-557. doi: 10.1016/s0006-291x(03)01212-9

28. Purvis, A. C. Diphenylamine inhibits respiration of green bell peppers [Text] / A. C. Purvis, J. W. Gegogeine // J Amer Soc Hort Sci. - 2003. - Vol. 128, Issue 6. - P. 924-929.

29. Liu, L. Intermittent warming improves postharvest quality of bell peppers and reduces chilling injury [Text] / L. Liu, Y. Wei, F. Shi, C. Liu, X. Liu, S. Ji // Postharvest Biology and Technology. - 2015. - Vol. 101. - P. 18-25. doi: 10.1016/j.postharvbio.2014.11.006

30. Yang, J. Reduction of Chilling Injury and Ultrastructural Damage in Cherry Tomato Fruits After Hot Water Treatment [Text] / J. Yang, M.-R. Fu, Y.-Y. Zhao, L.-C. Mao // Agricultural Sciences in China. - 2009. - Vol. 8, Issue 3. - P. 304-310. doi: 10.1016/ s1671-2927(08)60213-8

31. Golden, K. D. Ethylene in Postharvest Technology: A Review [Text] / K. D. Golden, O. J. Williams, H. M. Dunkley // Asian Journal of Biological Sciences. - 2014. - Vol. 7, Issue 4. - P. 135-143. doi: 10.3923/ajbs.2014.135.143 